\title{
Panchakarma Therapy for Simultaneous Management of Symptoms due to Multiple Complaints including Hypothyroidism, Leucorrhoea, Cervical Pain - A Case Report
}

\author{
Alka Mishra ${ }^{1}$, Saurabh Mishra ${ }^{2, *}$, Ashok Kumar Pandey ${ }^{1}$ \\ ${ }^{I}$ Department of Ayurveda and Holistic Health, Dev Sanskriti Vishwavidyalaya, Gayatrikunj- \\ Shantikunj, Haridwar, Uttarakhand, India \\ ${ }^{2}$ Dev Sanskriti Vishwavidyalaya, Gayatrikunj-Shantikunj, Haridwar, Uttarakhand, India \\ "Corresponding Author: Saurabh Mishra - Email: sau.dsvv@gmail.com
}

Cite this research article as follows:

Mishra A, Mishra S, Pandey AK. Panchakarma therapy for simultaneous management of symptoms due to multiple complaints including hypothyroidism, leucorrhoea, cervical pain - a case report. Ayurveda evam Samagra Swasthya Shodhamala. 2020;2(3):1. [cited date]. Available from: https://sites.google.com/dsvv.ac.in/shodhamala-dahh/asssm23/asssm231

\section{License information for readers:}

The original contents published in this research publication, which include research articles, case reports, etc., are published under the Creative Commons Attribution (CC BY 4.0) License. Anyone may reproduce, distribute, translate and create derivative works of this original content, subject to full attribution to the original research publication (Ayurveda evam Samagra Swasthya Shodhamala) and authors. The full terms of this license may be seen at https://creativecommons.org/licenses/by/4.0/

\section{Published by:}

Department of Ayurveda and Holistic Health

Dev Sanskriti Vishwavidyalaya

Gayatrikunj-Shantikunj, Haridwar - 249411

Uttarakhand, India

Email: dahh@dsvv.ac.in

Mobile: +91 9258360953, +91 8954890390

Website: http://www.dsvv.ac.in/dahh

Published online: 29 September 2020 


\begin{abstract}
Background: A case report about a female patient has been presented here, who was suffering from multiple complaints including hypothyroidism-(since more than 2 years), leucorrhoea, cervical pain, continuous feverish feeling-(since more than 12 years), etc. According to Ayurvedic texts, the multiple complaints experienced by the patient involve the vitiation of all the three Doshas, i.e. Vata, Pitta and Kapha. Panchakarma Therapy procedures are known to balance the three Doshas, as well as provide tissue nourishing, strengthening and rejuvenating effects.

Methodology: Panchakarma therapy was administered for 9 days to the patient. Therapeutic procedures and herbal medicines that pacify the three Doshas, and also provide strengthening, tissue nourishing and rejuvenating effect, were used.

Results: The patient experienced notable relief in continuous feverish feeling (90\%), neck pain $(70 \%)$, and white discharge $\mathrm{P} / \mathrm{V}(50 \%)$. The complaints of burning mictuition, weakness and fatigue were completely resolved. Overall, the patient was feeling energetic and happy after taking the therapy.

Conclusion: Panchakarma therapy showed encouraging results in the simultaneous management of symptoms associated with multiple complaints including hypothyroidism, leucorrhoea, cervical pain, continuous feverish feeling, as well as other associated ailments, in short duration of time.
\end{abstract}

Keywords: Hypothyroidism, Leucorrhoea, Cervical Pain, Chronic Fever, Ayurveda, Panchakarma, Herbal Medicine 


\section{Introduction}

This case report is about a female patient (age 37 years) who was suffering from multiple complaints including:

- Hypothyroidism (since more than 2 years)

- Severe Headache

- Cervical pain - radiates to right upper extremity

- White discharge P/V - sticky and thick, milky, odorless

- Delayed menstrual cycle - by one week (some relief with Homeopathy treatment)

- Continuous feverish feeling (since about 12 years)

- Vomiting sensation

- Body-ache, with pain in both the extremities

- Cold feeling in winter season (stays for 1-2 hours - subsides after taking 1-2 doses of allopathic medicine)

- Urine - burning mictuition (no treatment - self-managed)

- Feeling Depression - on and off

The patient had past history of:

- Enteric fever one year ago - treatment with allopathic medicine

- Feeling uneasy and fearful - on and off

The patient had no past history of diabetes mellitus, hypertension, tuberculosis, coronary artery disease, jaundice. The patient had normal appetite, sleep and stool.

Based on the above mentioned medical history, and further discussion with the doctor, the current diagnosis for the patient included hypothyroidism, with leucorrhoea, with delayed menstrual cycle, with cervical pain, with severe headache, with feverish feeling.

\section{Methodology}

Informed consent was obtained from the patient before the start of the therapy.

The prescribed therapeutic interventions were as follows:

\subsection{Therapeutic Intervention}

As mentioned above, the patient was suffering from multiple complaints including hypothyroidism, leucorrhoea, cervical pain, as well as other associated ailments. Furthermore, the patient had come to the Out Patient section, and had limited time to take the therapy; hence, the therapeutic intervention was planned accordingly.

The therapeutic intervention included Panchakarma therapy, which was administered to the patient over a period of 9 days as given in Table 1. Botanical names of medicinal plants used in the present study are given in Table 2.

As shown in Table 1, the patient was given Deepan Pachan drug on the first 3 days.

The snehan (oleation) therapies administered to the patient were as follows:

* Abhyangam (Sarvanga) (Full Body Massage) - on days 1, 2, 3 and 6. Abhyangam was done with a mixture of oils (Taila) including Dhanvantar Taila, Kottamchukyadi Taila and Sahacharadi Taila. 
* Abhyangam (Ekanga) (Local Massage) with a mixture of oils (Taila) including Dhanvantar Taila, Kottamchukyadi Taila and Sahacharadi Taila - on days 4 and 5

* Greeva Basti was given with a mixture of oils (Taila) including Dhanvantar Taila, Kottamchukyadi Taila and Sahacharadi Taila on days 1 to 6. Greeva Basti involves retaining the warm medicated oil over the cervical region (back of the neck) for certain period of time [1].

The snehan therapy was followed by swedan (sudation) therapy. The swedan therapies administered to the patient were as follows:

* Vashpa Sweda (Sarvanga) (Full Body Steam) was given on days 1, 2, 3 and 6

* Nadi Sweda (Local Steam) was given on days 4 and 5

* On last three days, Patra Pottali Sweda (Sarvanga) (Full Body) was administered to the patient along with mild Vashpa Sweda for wiping off the oil. Patra Pottali Sweda involves making a pottali (bundle) of leaves of medicinal plants in cotton cloth; keeping it in the mixture of oils mentioned in Table 1, that is continuously being heated; once the pottali is sufficiently heated, it is massaged over the entire body to induce sudation.

Before starting the Basti treatment, Virechan gulika + Avipattikar churna were given to the patient on day 4, for low-grade purification of gastro-intestinal tract (Koshtha Shuddhi); however, as it failed to provide the desired result, Virechan Vati-Myrolax + Avipattikar churna were given on day 5 for Koshtha Shuddhi, which gave the desired result.

Basti treatment was given to the patient for 4 days, from day 6 to 9 , wherein Anuvasana Basti (oil enema) was given on days 6 and 9, and Asthapana Basti (decoction enema) was given on days 7 and 8. Anuvasana Basti (oil enema) [2] and Asthapana Basti (decoction enema) [3] are the process of drug administration through the rectal route, wherein oil or other oleaginous substance is the major content in case of Anuvasana Basti, while medicated decoction is the major part in Asthapana Basti.

Nasya (nasal administration of medicine), with Bala Taila (numbers given in Table 1 represent the number of drops in each nostril), was administered to the patient on days 2 to 5 . The pre-procedure (purva karma) of Nasya involves doing massage (abhyangam) and hot fomentation (swedan) on the face and head [4-6]. This is followed by the main-procedure (pradhan karma) of Nasya, wherein the medicine is administered through the nasal route by pouring it, drop by drop, in both the nostrils [4]. Bala Taila contains Bala (Sida cordifolia) as the primary ingredient.

Shirodhara was administered to the patient on days 7,8 and 9. The procedure of Shirodhara involves continuous pouring of medicated liquid on the forehead of the patient, which creates specific pressure and vibration on the forehead $[7,8]$. Shirodhara was done with a mixture of Ksheerbala Taila, Karpooradi Taila and Til Taila. Ksheerbala Taila has cow's milk and Bala as primary ingredients, and Til Taila as base. The ingredients of Karpooradi Taila commonly include Ajamoda (Trachyspermum ammi), Karpoor (Cinnamomum camphorum) and Coconut oil [9] .

Local paste (Sthanika lepa) was administered on shoulder and hands on days 4, 5, 6 .

The patient was also given a Kwatha (decoction) of Vata pacifying (Vata-shamak), tissue nourishing and rejuvenating herbs on all the days.

Some other associated methodologies that were administered and the advice that was rendered along with the above therapeutic procedure are as follows.

Dietary restrictions were prescribed. Other behavioral regimen were also prescribed, 
such as, do not indulge in fear, anxiety, stress, anger, and any other negative thought; do not roam around too much; do not obstruct your natural urges like hunger, thirst, sleep, yawning, tear, etc. Try to keep your mind calm and happy, try to be silent, go early to bed and wake up early in the morning.

The doctor regularly talked to the patient about her condition, and provided both clinical and motivational guidance, i.e. did regular counseling with positive thoughts. Gayatri Mantra was played continuously during the therapy. 
Table 1: Therapeutic intervention administered to the patient over a period of 9 days. The letter ' $Y$ ' indicates that the therapeutic procedure mentioned in that row, was administered on that day.

\begin{tabular}{|c|c|c|c|c|c|c|c|c|c|}
\hline & \multicolumn{9}{|c|}{ Day } \\
\hline Therapeutic Intervention & 1 & 2 & 3 & 4 & 5 & 6 & 7 & 8 & 9 \\
\hline Deepan Pachan Drug (Shankha Vati) & $\mathrm{Y}$ & $\mathrm{Y}$ & $\mathrm{Y}$ & & & & & & \\
\hline $\begin{array}{l}\text { Abhyangam (Sarvanga) (Full Body Massage) with } \\
\text { Dhanvantar Taila }+ \text { Kottamchukyadi Taila }+ \\
\text { Sahacharadi Taila }\end{array}$ & $\mathrm{Y}$ & $\mathrm{Y}$ & Y & & & Y & & & \\
\hline Abhyangam (Ekanga) (Local Massage) of the above oils & & & & Y & Y & & & & \\
\hline $\begin{array}{l}\text { Greeva Basti with Dhanvantar Taila }+ \text { Kottamchukyadi } \\
\text { Taila }+ \text { Sahacharadi Taila }\end{array}$ & $\mathrm{Y}$ & $\mathrm{Y}$ & $\mathrm{Y}$ & Y & $\mathrm{Y}$ & Y & & & \\
\hline $\begin{array}{l}\text { Vashpa Sweda (Sarvanga) (Full Body Steam) of kwath } \\
\text { of Dashamoola + Erandamoola }\end{array}$ & $\mathrm{Y}$ & $\mathrm{Y}$ & $\mathrm{Y}$ & & & Y & & & \\
\hline $\begin{array}{l}\text { Nadi Sweda (Local Steam) of kwath of Dashamoola }+ \\
\text { Erandamoola }\end{array}$ & & & & Y & $\mathrm{Y}$ & & & & \\
\hline $\begin{array}{l}\text { Patra Pottali Sweda (Sarvanga) (Full Body) with } \\
\text { Dhanvantar Taila }+ \text { Kottamchukyadi Taila }+ \\
\text { Sahacharadi Taila }+ \text { Til Taila }\end{array}$ & & & & & & & Y & Y & Y \\
\hline $\begin{array}{l}\text { Koshtha Shuddhi through } Y 1=(\text { Virechan Gulika }+ \\
\text { Avipattikara Churna), Y2=(Virechan Vati-Myrolax }+ \\
\text { Avipattikara Churna) }\end{array}$ & & & & Y1 & Y2 & & & & \\
\hline Basti - Anuvasana with Kottamchukyadi Taila & & & & & & $\mathrm{Y}$ & & & $Y$ \\
\hline $\begin{array}{l}\text { Basti - Asthapana with kwatha of Dashamoola }+ \\
\text { Erandamoola }+ \text { Triphala }+ \text { Nirgundi }+ \text { Rasna }+ \\
\text { Nagaramotha }+ \text { Bala }+ \text { Giloy }+ \text { Kachanar }+ \text { Kalmegh }\end{array}$ & & & & & & & $Y$ & $\mathrm{Y}$ & \\
\hline $\begin{array}{l}\text { Nasya with Bala Taila (numbers represent the number of } \\
\text { drops in each nostril) }\end{array}$ & & 6 & 7 & 7 & 8 & 8 & & & \\
\hline $\begin{array}{l}\text { Shirodhara with Ksheerbala Taila + Karpooradi Taila }+ \\
\text { Til Taila }\end{array}$ & & & & & & & $Y$ & $Y$ & $\mathrm{Y}$ \\
\hline $\begin{array}{l}\text { Lepa (thin coating) (shoulder and hands) with paste } \\
\text { made from Dashamoola }+ \text { Erandamoola }+ \text { Eranda beej } \\
(\text { seeds })+\text { Eranda patra (leaves) }+ \text { Til Taila }\end{array}$ & & & & $\mathrm{Y}$ & $Y$ & $Y$ & & & \\
\hline $\begin{array}{l}\text { Kwatha of Dashamoola }+ \text { Bala }+ \text { Giloy }+ \text { Nirgundi }+ \\
\text { Rasna }+ \text { Nagarmotha }+ \text { Ashwagandha }+ \text { Yashtimadhu } \\
+ \text { Kalmegh }+ \text { Punarnava }+ \text { Daruharidra }\end{array}$ & $\mathrm{Y}$ & $\mathrm{Y}$ & $\mathrm{Y}$ & $\mathrm{Y}$ & $\mathrm{Y}$ & $Y$ & $\mathrm{Y}$ & $\mathrm{Y}$ & $\mathrm{Y}$ \\
\hline
\end{tabular}


Table 2: Botanical names of medicinal plants used in the present study.

\begin{tabular}{|c|c|}
\hline Common Name & Botanical Name \\
\hline \multicolumn{2}{|c|}{ Dashamoola (Roots of ten plants) } \\
\hline \multicolumn{2}{|c|}{$\begin{array}{l}\text { (a) Laghu Panchamoola (roots / whole plant of } 5 \\
\text { shrubs) }\end{array}$} \\
\hline Shalaparni & Desmodium gangeticum \\
\hline Prishnaparni & Uraria picta \\
\hline Brihati & Solanum indicum \\
\hline Kantakari & Solanum xanthocarpum \\
\hline Gokshuru & Tribulus terrestris \\
\hline \multicolumn{2}{|c|}{ (b) Brihat Panchamoola (roots of 5 trees) } \\
\hline Bilva & Aegle marmelos \\
\hline Agnimanth & Clerodendrum phlomidis \\
\hline Gambhari & Gmelina arborea \\
\hline Shyonak & Oroxylum indicum \\
\hline Patala & Stereospermum suaveolens \\
\hline \multicolumn{2}{|c|}{ Triphala (combination of 3 fruits) } \\
\hline Amalki & Emblica officinalis \\
\hline Haritaki & Terminalia chebula \\
\hline Vibhitaki & Terminalia bellirica \\
\hline Erandamoola & root of Ricinus communis \\
\hline Eranda beej & seed of Ricinus communis \\
\hline Eranda patra & leaf of Ricinus communis \\
\hline Nirgundi & Vitex negundo \\
\hline Rasna & Pluchea lanceolata \\
\hline Nagarmotha & Cyperus rotundus \\
\hline Bala & Sida cordifolia \\
\hline Giloy & Tinospora cordifolia \\
\hline Kachanar & Bauhinia variegata \\
\hline Kalmegh & Andrographis paniculata \\
\hline Ashwagandha & Withania somnifera \\
\hline Yashtimadhu & Glycyrrhiza Glabra \\
\hline Punarnava & Boerhavia diffusa \\
\hline Daruharidra & Berberis aristata \\
\hline
\end{tabular}




\section{Results}

In this case report, the outcomes were assessed in a qualitative (subjective) manner based on the doctor's pre and post examination, and, patient's experiential feedback, as given in Table 3. During the administration of the therapy, the day-wise effects and experience, reported by the patient, are given in Table 4 .

Table 3: Pre Therapy and Post Therapy Observations

\begin{tabular}{|l|l|}
\hline Pre Therapy Observation & Post Therapy Observation \\
\hline Feverish feeling - all the time & About $90 \%$ relief \\
\hline White discharge P/V & About $50 \%$ relief \\
\hline Neck pain & About $70 \%$ relief \\
\hline Burning mictuition & No burning now \\
\hline Weakness with fatigue & No weakness \\
\hline & $\begin{array}{l}\text { Overall, the patient was feeling energetic and } \\
\text { happy after taking the therapy }\end{array}$ \\
\hline
\end{tabular}

As given in Table 3, before the start of the therapy the patient reported feverish feeling (all the time); after 9 days of the Panchakarma treatment, the patient reported about $90 \%$ relief in this complaint.

Before the start of the therapy, the patient reported white discharge $\mathrm{P} / \mathrm{V}$; after the therapy the patient reported about $50 \%$ relief in this complaint.

Before the start of the therapy, the patient experienced neck pain; after the therapy the patient reported about $70 \%$ relief in this complaint.

Before the start of the therapy, the patient reported burning mictuition; after the therapy the patient reported complete relief in this complaint.

Before the start of the therapy, the patient was experiencing weakness with fatigue; after the therapy the patient reported no weakness.

Overall, the patient was feeling energetic and happy after taking the therapy. 
Table 4: Day-wise effects and experience reported by the patient

\begin{tabular}{|c|l|}
\hline Day & Effect / Experience reported by the patient \\
\hline 3 & $\begin{array}{l}\text { Relief in headache - earlier the headache used to be there all the time, now it is there } \\
\text { only occasionally }\end{array}$ \\
\hline 4 & $\begin{array}{l}\sim 50 \% \text { relief in the pain in the hand (on the shoulder); some relief in leucorrhoea as } \\
\text { well }\end{array}$ \\
\hline 5 & Earlier there used to be feverish feeling all the time - now there is no feverish feeling \\
\hline 6 & Body feels light \\
\hline 7 & $\begin{array}{l}\text { normal motion, no fever, no headache ; although there is pain in the waist, neck, right } \\
\text { hand, but it is less than what used to be there earlier ; there is light cough also }\end{array}$ \\
\hline 8 & $\begin{array}{l}\text { There was no pain the previous night, in shoulder, neck, waist - had sound sleep ; } \\
\text { normal motion in the morning }\end{array}$ \\
\hline 9 & \begin{tabular}{l}
$\sim 10 \%$ pain remaining in shoulder, waist ; normal motion \\
\hline
\end{tabular}
\end{tabular}

It can be seen from Table 4 that the patient experienced continous relief in various disease symptoms during the course of the therapy.

\section{Discussion}

The present study illustrates the potential of Panchakarma Therapy for the treatment of a patient suffering from multiple complaints including hypothyroidism, leucorrhoea, cervical pain, continuous feverish feeling, as well as other associated ailments.

According to Ayurveda, a healthy human body is supposed to have a relatively stable equilibrium (congenial homeostasis) of Dosha (psycho-biological rhythm - Vata, Pitta, Kapha), Dhatu (body tissues and their nourishing elements) and Mala (excreta) [10,11]; Acharya Sushruta defines health as an equilibrium of Dosha (psycho-biological rhythm), Agni (digestion and metabolism), Dhatu (body tissues), Malakriya (excretory function), as well as the well being of soul, senses and mind [10,11]. Imbalance in this equilibrium leads to disease, and the aim of the therapy is to restore this balance [11-13].

As per Ayurvedic texts $[11,13,14]$, the cause for the multiple complaints experienced by the patient may be attributed to the vitiation of all the three Doshas, i.e. Vata, Pitta and Kapha; therefore, the Panchakarma therapy was administered to the patient accordingly.

The results given in Table 3 indicate that Panchakarma therapy gives encouraging outcomes, even in short duration. These results may be attributed to the therapeutic action of various Ayurvedic procedures administered to the patient.

To begin with, Deepan Pachan medicines are administered for enhancing the digestive fire $[15,16]$, for digestion of the Ama Dosha (undigested toxins of the body that are responsible for the blockage of micro-channels, i.e. srotas), as well as for the preparation of the body for next therapies.

The snehan (oleation) and swedan (sudation) therapies are useful in balancing the Vata Dosha [11,13]. The oils used in snehan therapies have snigdha (unctuous), guru (heavy) and mridu (soft) properties, which are opposite to the properties of Vata; hence, Abhyangam and Greeva Basti reduces the vitiated Vata (which is responsible for the decay in the dhatus) 
[17]. Also, in the present study, the oils chosen for Abhyangam and Greeva Basti were such, whose ingredients balance the Kapha and Pitta Doshas as well. Besides balancing the vitiated Doshas, the oils also provide nourishing effect (vrinhan) to the degenerative tissues, and, have balya (strengthening) and rasayana (rejuvenating) properties [18,19].

Swedan has actions like stambhaghna (relieves stiffness), sweda-karak (creates perspiration), and, gauravaghna (cures heaviness) [17]. The medicinal herbs used in Vashpa Sweda have Vata pacifying (Vata-shamak) and tissue nourishing (vrinhan) properties [18,19]. The oils and herbs used in Patra Pottali Sweda balance all the three Doshas, and have vrinhan (tissue nourishing), balya (strengthening) and rasayana (rejuvenating) properties [18,19].

The Koshtha Shuddhi procedure does a low-grade purification of the gastro-intestinal tract, and prepares the body for the Basti treatment.

Basti is one of the best treatment in the case of Vata disorders [3], as stated by Acharya Charak (Vastirvaataharaannaam) \{Charak Samhita - Sutra Sthan 25/40\} [20]. Anuvasana Basti (oil enema) nourishes the dhatus, promotes strength and cures Vata related diseases; Asthapana Basti (decoction enema) cleanses the colon and cures Vata related diseases [3]. Also, the herbs and oil used in Basti were such, which balance the Kapha and Pitta Doshas as well.

The pre-procedure (purva karma) of Nasya causes the softening and liquifying of the vitiated Doshas [4-6]. The vasodilation caused by the pre-procedure is supposed to increase the permeability of the blood vessels, which makes the absorption of the medicine faster [5]. The main-procedure (pradhan karma) of Nasya involves administering the medicinal oil through the nasal route, by pouring it, drop by drop, in both the nostrils [4]. Nasya primarily affects the urdhvajatrugata pradesha (supra-clavicular region) [4,21]. According to Acharya Vagbhatta, nose is one of the most convenient routes to convey medicinal effects to the cranial cavity [4]. According to Acharya Charaka, nasya drug usually acts through absorption by the Shringataka marma (a vital spot in the head region situated at the site of the union of the nerves, supplying to the nose, ears, eyes, and tongue); after absorption, the medicine acts on the diseases of head, shoulder, neck, etc., and the vitiated Doshas are expelled from the head region [4]. Thus, the administered medicine moves up to the Shringataka marma, spreads all over the head, channels of eyes, ears and throat, and removes vitiated Doshas from there [4,21]. Nasya was done with Bala Taila, which has beneficial effect on all the sensory organs, and affects the mind in such a way that the patient experiences relief from anxiety and stress [7].

Shirodhara creates specific pressure and vibration on the forehead, with beneficial therapeutic effect in terms of relieving stress, anxiety, etc. [7,8]. Shirodhara was done with Ksheerbala Taila, Karpooradi Taila and Til Taila. The ingredients of Ksheerbala Taila have Vata pacifying, balya (strengthening) and vrinhan (tissue nourishing) properties [18,19]; milk has madhura rasa (sweet in taste), snigdha guna (oily property), sheeta veerya (cold in nature) and madhura vipaka (effect after bio-transformation), which pacify Vata and Pitta Doshas [8]. The ingredients of Karpooradi Taila have Kapha and Vata pacifying properties [18,19].

Local paste (Sthanika lepa) was also administered on shoulder and hands, to provide relief from pain. The herbal ingredients used therein have Vata pacifying and tissue nourishing properties $[18,19]$.

The patient was also given a Kwatha (decoction) of Vata pacifying (Vata-shamak), strengthening (balya), and tissue nourishing (vrinhan) herbal medicines [18,19].

Almost daily the doctor talked to the patient about her condition, and provided both clinical and motivational guidance; the purpose was to instill confidence in the patient that her condition can be improved, and she has to herself take responsibility of bringing about this change by diligently following the prescribed treatment and guidelines. 
Each therapy was started with the chanting of Gayatri Mantra, which causes beneficial effects with regards to various physical and mental conditions like attention, concentration, etc. [22-27]. The patient must also have benefited from the spiritually charged environment of Dev Sanskriti Vishwavidyalaya, Haridwar.

During Panchakarma therapy, it is advised to avoid 'Ashta-Maha-Doshkar-Bhav' (eight types of behavioral and dietetic practices that cause obstructions in micro-channels, srotas, leading to aggravation of the diseases) so that better results can be observed. The following of these practices must also have contributed in providing the observed relief.

The above discussion reveals that since the complaints of the patient were associated with the vitiation of all the three Doshas, hence, the therapeutic procedures administered to the patient had Vata, Pitta and Kapha pacifying, tissue nourishing (vrinhan), strengthening (balya), and rejuvenating (rasayan) effects, which must have caused the amount of relief experienced by the patient in such a short duration of therapy. Also, in place of using a single therapy, a combination of different therapeutic procedures, along with multiple herbs, were used, in order to achieve simultaneous management of the symptoms associated with multiple ailments.

Although the results are qualitative in nature, yet the degree of benefit attained in simultaneously addressing multiple types of ailments is noteworthy, especially considering the fact that the patient was an Outdoor Patient, had genuine limitations in following the dietary restrictions, and the therapy was administered for quite short duration.

Further in-depth quantitative study would definitely be worthwhile to establish the mode of operation of the administered therapeutic procedure in the light of modern scientific understanding.

\section{Conclusions}

Panchakarma therapy was administered in the present study for the simultaneous management of symptoms due to multiple complaints including hypothyroidism, leucorrhoea, cervial pain, as well as associated ailments. A single case study involving female patient was presented. Various therapeutic procedures were administered to the Out Patient section patient over a period of 9 days. Qualitative analysis showed encouraging results, with the patient experiencing relief in various symptoms associated with the multiple complaints, in a short duration of time.

\section{Acknowledgements}

Authors would like to acknowledge the subtle guidance of their spiritual guide, Revered Pandit Shriram Sharma Acharya (http://www.awgp.org/about_us/patron_founder), who founded the organization - All World Gayatri Pariwar. The authors thank the faculty and staff of the Department of Ayurveda and Holistic Health, Dev Sanskriti Vishwavidyalaya, Haridwar for their support in conducting this study

\section{Compliance with ethical standards}

Informed consent was obtained from the patient before the start of the therapy.

\section{Conflict of interest}

The authors declare that they have no conflict of interest. 


\section{References}

1. Acharya GS. Panchakarma illustrated. Delhi: Chaukhamba Sanskrit Pratishthan; 2006.

2. Kadus PA, Vedpathak SM. Anuvasan basti in escalating dose is an alternative for snehapana before vamana and virechana: trends from a pilot study. Journal of Ayurveda and Integrative Medicine. 2014; 5(4): 246-250.

(https://www.ncbi.nlm.nih.gov/pmc/articles/PMC4296438/)

3. Gundeti MS, Raut AA, Kamat NM. Basti: does the equipment and method of administration matter? Journal of Ayurveda and Integrative Medicine. 2013; 4(1): 9-12. (https://www.ncbi.nlm.nih.gov/pmc/articles/PMC3667437/)

4. Das B, Ganesh RM, Mishra PK, Bhuyan G. A study on apabahuka (frozen shoulder) and its management by laghumasha taila nasya. Ayu. 2010; 31(4): 488-494.

(https://www.ncbi.nlm.nih.gov/pmc/articles/PMC3202264/)

5. Chaudhari V, Rajagopala M, Mistry S, Vaghela DB. Role of pradhamana nasya and trayodashanga kwatha in the management of dushta pratishyaya with special reference to chronic sinusitis. Ayu. 2010; 31(3): 325-331.

(http://www.ayujournal.org/article.asp?issn $=0974-$

8520; year $=2010$; volume $=31$; issue $=3$; spage $=325$; epage $=331$; aulast $=$ Chaudhari)

6. Gupta DP, Rajagopala M, Dhiman KS. A clinical study on Akshitarpana and combination of akshitarpana with nasya therapy in timira with special reference to myopia. Ayu. 2010; 31(4): 473-477.

(https://www.ncbi.nlm.nih.gov/pmc/articles/PMC3202262/)

7. Kundu C, Shukla VD, Santwani MA, Bhatt NN. The role of psychic factors in pathogenesis of essential hypertension and its management by shirodhara and sarpagandha vati. Ayu. 2010; 31(4): 436-441.

(http://www.ayujournal.org/article.asp?issn $=0974-$

8520 ; year $=2010$; volume $=31$; issue $=4$; spage $=436$; epage $=441$; aulast $=$ Kundu $)$

8. Pokharel S, Sharma AK. Evaluation of insomrid tablet and shirodhara in the management of anidra (insomnia). Ayu. 2010; 31(1): 40-47.

(https://www.ncbi.nlm.nih.gov/pmc/articles/PMC3215320/)

9. Hepsibah PTA, Prasad NBR, Kumar PS. Standardisation of ayurvedic oils. Ancient Science of Life. 1998; 17(4): 280-283.

(https://www.ncbi.nlm.nih.gov/pmc/articles/PMC3331126/)

10. Kadlimatti SM, Maheshwari KS, Chandola HM. Critical analysis of the concept of asthi kshaya vis-a-vis osteoporosis. Ayu. 2009; 30(4): 447-58.

(http://www.ayujournal.org/temp/Ayu304447-2819005_074950.pdf)

11. Murthy KRS. Susruta samhita - Vol. I, II, III. Varanasi, Uttar Pradesh, India: Chaukhambha Orientalia; 2008.

12. Nagral KS. Ayurved for modern medical practitioners. Delhi, India: Chaukhamba Sanskrit Pratishthan: 2008.

13. Sharma PV. Charaka-samhita (text with English translation). volume I, II. Varanasi, Uttar Pradesh, India: Chaukhambha Orientalia; 2008.

14. Shastri S. Madhava nidanam of sri madhavakara (Hindi). part-1. 30th ed. Varanasi, Uttar Pradesh, India: Chaukhamba Sanskrit Sansthan; 2000.

15. Dudhamal TS, Gupta SK, Bhuyan C, Singh K. The role of apamarga kshara in the treatment of arsha. Ayu. 2010; 31(2): 232-235.

(http://www.ayujournal.org/article.asp?issn $=0974-$

8520 ; year $=2010 ;$ volume $=31 ;$ issue $=2 ;$ spage $=232$; epage $=235$; aulast $=$ Dudhamal) 
16. Lekurwale PS, Pandey K, Yadaiah P. Management of amavata with 'amrita ghrita': a clinical study. Ayu. 2010; 31(4): 430-435.

(http://www.ayujournal.org/article.asp?issn $=0974-$

8520; year $=2010$; volume $=31$; issue $=4$; spage $=430$; epage $=435$; aulast $=$ Lekurwale)

17. Sharma MR, Mehta CR, Shukla DJ, Patel KB, Patel MV, Gupta SN. Multimodal ayurvedic management for sandhigata vata (osteoarthritis of knee joint). Ayu. 2013; 34(1): 49-55.

(http://www.ayujournal.org/article.asp?issn $=0974-$

8520; year $=2013$; volume $=34$; issue $=1$; spage $=49$; epage $=55$; aulast $=$ Sharma)

18. Sharma PV. Dravyaguna vijnana - volume II (vegetable drugs) (hindi). Varanasi, Uttar Pradesh, India: Chaukhambha Bharati Academy; 2001.

19. Misra B, Vaisya R. Bhavaprakasa of shri bhava misra (including bhavaprakasa nighantu portion) - edited with the 'vidyotini' hindi commentary, notes and appendix - first part. Varanasi, Uttar Pradesh, India: Chaukhambha Sanskrit Bhawan; 2013.

20. Shastri K, Chaturvedi GN. Charak samhita - elaborated vidyotini hindi commentary. PartI. Varanasi, Uttar Pradesh, India: Chaukhamba Bharati Academy; 2001.

21. Radhika C, Kumar GV, Mihirjan K. A randomized controlled clinical trial to assess the efficacy of Nasya in reducing the signs and symptoms of cervical spondylosis. Ayu. 2012; 33(1): 73-77.

(http://www.ayujournal.org/temp/Ayu33173-2813369_074853.pdf)

22. Brahmavarchas. Yagya - ek samagra upachar prakriya (Hindi). Pandit Shriram Sharma Acharya samagra vangamaya. volume 26. revised ed. Mathura, Uttar Pradesh, India: Akhand Jyoti Sansthan; 2012.

23. Brahmavarchas. Shabda brahma - nad brahma (Hindi). Pandit Shriram Sharma Acharya samagra vangamaya. volume 19. 2nd ed. Mathura, Uttar Pradesh, India: Akhand Jyoti Sansthan; 2012.

24. Sharma S. Super science of gayatri. revised ed. translation by Pandya SN, Shambhudas. Mathura, Uttar Pradesh, India: Yug Nirman Yojana Vistar Trust, Gayatri Tapobhumi; 2010.

(http://literature.awgp.org/book/Super_Science_of_Gayatri/v1.1)

25. Sharma S. Gayatri mahavigyan - sanyukta sanskaran (Hindi). revised ed. Mathura, Uttar Pradesh, India: Yug Nirman Yojana Vistar Trust, Gayatri Tapobhumi; 2010.

(http://literature.awgp.org/book/Super_Science_of_Gayatri/v2)

26. Malhotra V, Goel N, Dhar U, Garg R, Tripathi $\bar{Y}$. Comparison of mind control techniques: an assessment of reaction times. Bangladesh Journal of Medical Science. 2016; 15(4): 596-600.

(https://www.banglajol.info/index.php/BJMS/article/view/30718)

27. Pradhan B, Derle SG. Comparison of effect of gayatri mantra and poem chanting on digit letter substitution task. Ancient Science of Life. 2012; 32(2): 89-92.

(https://www.ncbi.nlm.nih.gov/pmc/articles/PMC3807963/) 